\title{
Crablet of Mangrove Crab, Scylla olivacea Rearing at the Different Salinity Regimes
}

\author{
Gunarto and Andi Parenrengi \\ Research and Development for Coastal Aquaculture, Maros, South Sulawesi, Indonesia
}

\begin{abstract}
High canibalisms in crablet of mangrove crab, S. olivacea stage was resulted lower juvenile crab production. The objectives of the research is to know the efectiveness of crablet rearing at the different salinity regimes in floating plastic glass individually to minimize canibalism. Research was conducted at mud crab hatcheri Marana Station of RICA Maros. Day-7 crablet produced from a hatchery, and then reared individually in plastic glass provided with small holes in glass to enter water inside the glass. Crablet were stocked inside of the plastic glass individually, then it sets in a floating cage constructed with bamboo fenced, where a piece of styrofoam as they float in surface water in the aquarium. Nine aquariums each size $29 \times 60 \times 34.5 \mathrm{~cm}$ randomly was filled $30 \mathrm{~L}$ saline water with different salinity regimes, i. e. (A) 5 ppt, (B) 10 ppt, (C) 20 ppt, (D) 30 ppt. Each treatment in the three replications. Monitoring was conducted on growth increment (total weight and carapace width) and survival rate of crablet during one month rearing. Water quality monitored on dissolved oxygen, water temperature and alkalinity. Result of the research was showing that the highest growth increment of crablet was obtained in A treatment $(0.74 \pm 0.13 \mathrm{~g})$ and significantly different $(P<0.05)$ with $D$ treatment, but there was not significantly different $(P>0.05)$ with $B(0.57 \pm 0.10 \mathrm{~g})$ and $C$ treatment $(0.61 \pm 0.15 \mathrm{~g})$. The carapace width was significantly different $(P<0.05)$ between $A$ and $B, A$ and $D, B$ and $C, B$ and $D, C$ and $D$. The highest of survival rate $(100 \%)$ was obtained in $C$ treatment and significant different $(P<0.05)$ with $A$ treatment $(73.3 \pm 11.55 \%)$. However, there were not significantly different $(P>0.05)$ with $B$ and $D$ treatment.
\end{abstract}

Keywords: Crabling; Crablet; Salinity; Growth; Survival rate

\section{Introduction}

Mangrove crab, Genus Scylla is one of the fisheries commodities with high economic value in Asia Pacific region, there were found four species under genus Scylla, namely S. serrata, S. transquebarica, $S$. olivacea dan S. paramamosain by Keenan [1].

Mangrove crab growout has been conducted in some area of Indonesia, for instance, in brackishwater pond on the Cenranae mouth river, Bone Regency, South Sulawesi [2], Segara Anakan, Cilacap, Central Java [3] and in Muncar, Banyuwangi, East Java. Soft shell crab production was also developed in some area of Indonesia, such as Barru and Takalar regency, South Sulawesi. Whereas in Pemalang and Brebes regency, Central Java, beside produced soft shell crab also produced mud crab gonadal maturation [4]. Most of them the juvenile and unberried female of mud crab provided from crabbing in the wild.

Since 20 years ago an effort of research was conducted to find out mangrove crab seed production technique. However, complete technique for crablet production is still uncomfortable, cause of low percentage $(<5 \%)$ of crablet production still and fluctuative. The newest research focused to give attention to the kind of container for megalops rearing. Gunarto [5,6] tested different kind of tanks for megalops rearing namely, (A) circular fiberglass tank volume 4 tons, (B) circular cement tank volume 4 tons, and (C) rectangular cement tank volume 4 ton, they found that the highest crablet-D7 production in A treatment $(40.14 \pm 0.424 \%)$, followed by $C$ treatment $(34.65 \pm 11.101 \%)$ and the lowest in C treatment $(22.675 \pm 0.954 \%)$.

Some constrains encountered in larvae rearing was larvae mortality caused by a bacterial infection such as Vibrio harveyi [7], unsyncronizing of zoea- 5 metamorphosis to the megalops, and low vitality of larvae cause mass mortality of megalops [7]. High cannibalisms in megalops also find out in crablet, juvenile and adult stages. Molt crab most often cannibalism by a unmolt crab. Research on seaweed, Gracilaria sp as shelter in crablet rearing was observed that a half of bottom width spreaded with Gracillaria sp as a shelter was found the survival rate at $49.9 \%$ during the 30 days rearing, while without shelter, the survival rate at 23\% [8-10]. From these data can be concluded that even though the shelter was used in crablet rearing, there were still resulted low survival rate of crablet. This research aimed to know the effectiveness of individually crablet rearing in plastic glass floating cages at the different salinity regimes.

\section{Material and Method}

Research was conducted in mud crab hatchery of Pond Station Marana, RICA Maros. Crablet of Scylla olivacea provided from hatchery at the range weight $0.04-0.09 \mathrm{~g}$ and carapace width $5-10 \mathrm{~mm}$, individually stocked in plastic glass, then they are settled in a floating cage constructed with bamboo fenced, where a piece of styrofoam as the float in surface water in the aquarium. Each floating cage in each aquarium stocked with five crablet in five plastic glasses (Figure 1). A total of twelve of aquariums each size $29 \times 60 \times 34.5 \mathrm{~cm}$ were filled of brackish water pond maintained at different salinity regimes as the treatment, namely: (A) $5 \mathrm{ppt}$, (B) $10 \mathrm{ppt}$, (C) $20 \mathrm{ppt}$ and (D) $30 \mathrm{ppt}$. Each treatment in the three replications.

Small copfish was given as feed ad libitum to the crablet in the

*Corresponding author: Gunarto Gun, Research Institute for Coastal Aquaculture, Jln. M. Dg. Sitakka No. 129 Maros, South Sulawesi 90512, Indonesia, Tel: 62081342788509; Fax: 620411431545; E-mail: gunartom@yahoo.com

Received June 13, 2014; Accepted July 28, 2014; Published August 06, 2014

Citation: Gunarto and A. Parenrengi (2014) Crablet of Mangrove Crab, Scylla olivacea Rearing at the Different Salinity Regimes. J Aquac Res Development 5: 255 doi:10.4172/2155-9546.1000255

Copyright: ( 2014 Gunarto, et al. This is an open-access article distributed under the terms of the Creative Commons Attribution License, which permits unrestricted use, distribution, and reproduction in any medium, provided the original author and source are credited. 
every morning at 8.00-9.00, and the rest of feed was picked out in every morning before fresh feed was given to the crablet. Water exchange at $5 \%$ of total volume of water in each aquarium was conducted at every two days. Some biological parameters were monitored be weekly mainly in body weight increment, length and width carapace. Crablet survival rate in each treatment was monitored after one month reared. Water quality monitored in situ, namely water temperature, salinity, $\mathrm{pH}$. $300 \mathrm{~mL}$ water sample from each aquarium brought to the laboratory for analyzing ammonium, nitrite and total organic matter (TOM). Complete Random Design was applied to the growth data obtained followed by a Duncan test to know significantly different among the treatments tested.

\section{Result and Discussion}

The crablet S. olivacea growth was shown in Figure 1. In the first two weeks until one month rearing showed that crablet in A treatment, salinity $5 \mathrm{ppt}$ tend to grow faster compared than that of the crablet grow in the other treatments. The mean weight of the crablet after one month reared individually inside the plastic glass was $0.80 \mathrm{~g} /$ pieces $(\mathrm{A})$, $0.64 \mathrm{~g} /$ pieces (B), $0.71 \mathrm{~g} /$ pieces $(\mathrm{C})$ and $0.54 \mathrm{~g} /$ pieces $(\mathrm{D})$ treatment.

The daily growth rate was $0.024 \mathrm{~g} /$ day (A), $0.018 \mathrm{~g} /$ day (B), $0.021 \mathrm{~g} /$ day $(\mathrm{C})$ and $0.015 \mathrm{~g} /$ day $(\mathrm{D})$. Statistical analysis showed that the daily growth rate of the crablet in A treatment showed significantly different $(\mathrm{P}<0.05)$ with $\mathrm{D}$ treatment. However, there was not significantly different $(\mathrm{P}>0.05)$ with $\mathrm{B}$ and $\mathrm{C}$ treatments. $\mathrm{B}$ and $\mathrm{C}$ treatment were also were not significantly different with $\mathrm{D}$ treatment $(\mathrm{P}>0.05)$ (Table 1). Earlier studies, Gunarto was observed that crablet weight at 0.31 $0.52 \mathrm{~g}$ reared at the salinity $25 \mathrm{ppt}$ during one month was resulted grow increment in the range 1.69-1.98 g (Figure 2).

Mia and Syah [9] in Bangladesh was observed that S. serrata juvenile with initial weight $1.10-1.95 \mathrm{~g}$ and the highest growth increment obtained at the crablet reared at the salinity $25 \mathrm{ppt}$, with specific growth rate at $4.46 \% /$ day and showed significantly different $(\mathrm{P}<0.05)$ with the crablet growth increment at the salinity 10 and 5 ppt. However, there were not significantly different $(\mathrm{P}>0.05)$ with salinity 20 and $15 \mathrm{ppt}$. Junaedah [10] declared that crab seed $S$. paramamosain reared in the soil substrat resulted significant gowth rate $(\mathrm{P}<0.01)$ compared than that of crab seed reared in the san substrat.

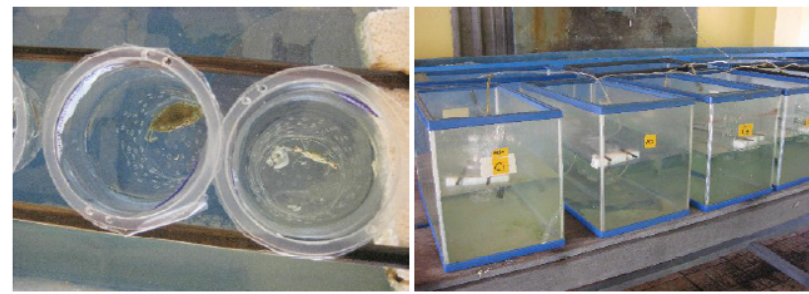

Figure 1: Plastic glasses with some hole in the bottom and float in the surfacewater of aquarium used as individually rearing of crabletS. olivacea.
Mangrove crab, S. olivacea morpho and ecologically different with S. serrate as well as $S$. paramamosain. S. olivacea in the wild obtained in mouth river area and mangrove estuary with dominated by Nypa sp, as was seen in mouth river on Cenranae river, Bone Regency, South Sulawesi. Lewis [11], claimed that $S$. olivacea are suitable species for stocking enhancement in mangrove area, because of their habitat in hole of mangrove area, while $S$. paramamosain and S. serrate their habitat more width reach to the sea area.

The mouth river usually with salinity lower than $30 \mathrm{ppt}$, by that reason S. olivacea commonly found in the lower salinity area. This phenomenon was proven by fast growth rate of crablet $S$ olivacea at the salinity $5 \mathrm{ppt}$ and showed significantly different $(\mathrm{P}<0.05)$ with crablet $S$. olivacea growth rate at the salinity $30 \mathrm{ppt}$. By this research can be summarized that the good salinity for crablet $S$ olivacea growth (0.07-0.08 g/pieces was at the range 5-20 ppt. Mangrove crab, $S$. olivacea presumably like tiger shrimp, Penaeus monodon in the salinity adaptation process, where both of them were euryhaline species. The growth rate of tiger shrimp at the salinity 10-20 ppt was higher compared than that of the growth rate at the salinity $30 \mathrm{ppt} \mathrm{[12].}$

The highest crablet survival rate was obtained in the $\mathrm{C}$ treatment (100\%), then followed by B and D treatment and the lowest was A treatment (73.3\%) (Figure 2). The lowest of the crablet survival rate should not be affected to the highest of crablet growth rate such as in A treatment. It caused not any competition on the feed and space, because crablet reared individually in plastic glass, except if any crablet enter to the neighbour plastic glass and was occuring cannibalisms among crablet and resulted one or both of the crablet were dead. Junaedah [10] was found that crablet survival rate significantly affected by a kind of substrate, where san substrate resulted significantly higher survival rate of crablet $(\mathrm{P}<0.05)$ compared than that crablet reared with muddy substrate. Rearing crablet using seaweed, Gracillaria sp as a shelter, Gunarto [8] found that a half of surface bottom with Gracilaria sp as a shelter resulted survival rate $49.99 \pm 23.56 \%$, was higher compare than that $100 \%$ of surface bottom spread with Gracilaria sp the crablet survival rate $33.33 \pm 0 \%$, while without shelter, the crablet survival rate was $24.99 \pm 11.78 \%$. Based on this data can be concluded that individually crablet rearing in plastic glass resulted higher survival rate compared than that of crablet rearing using Gracillaria sp as a shelter (Figure 3).

In A treatment, crablet mortality was caused by molt failure. Greenaway [13], stated that in crab molting was occured calcium ion transportation from and to carapace exdyces, where chitine biosynthesis and degradation was occured. Beside calcium, some hormonal also required in molting process, for instances chitinase, chitobiase, carbonic anhidrase, alcalin phosphatase, Ca \pm ATPase, proteinase, trace element dan glicogen $[14,15]$. In A treatment where salinity only 5 ppt may calcium ion and hormonal required in molting process insufficient to support complete molting process, so that some crablets failure molt and furthermore die. The different condition, when the crablet reared at the salinity $20 \mathrm{ppt}$, may calcium and hormonal

\begin{tabular}{|c|c|c|c|c|c|c|}
\hline Treatment & Initial weight (g) & Final weight (g) & Growth increment (g) & Initial carapace width $(\mathrm{cm})$ & Final carapace width $(\mathrm{cm})$ & Growth of carapace width $(\mathrm{cm})$ \\
\hline$A=5 \mathrm{ppt}$ & $0.07 \pm 0.01$ & $0.80 \pm 0.13$ & $0.74 \pm 0.13^{a}$ & $0.90 \pm 0.02$ & $1.46 \pm 0.01$ & $0.56 \pm 0.01^{a}$ \\
\hline $\mathrm{B}=10 \mathrm{ppt}$ & $0.07 \pm 0.03$ & $0.64 \pm 0.10$ & $0.57 \pm 0.10^{\mathrm{ab}}$ & $0.92 \pm 0.01$ & $1.32 \pm 0.08$ & $0.39 \pm 0.08^{c}$ \\
\hline $\mathrm{C}=20 \mathrm{ppt}$ & $0.08 \pm 0.02$ & $0.71 \pm 0.13$ & $0.61 \pm 0.15^{\mathrm{ab}}$ & $0.94 \pm 0.03$ & $1.46 \pm 0.04$ & $0.52 \pm 0.04^{\mathrm{ad}}$ \\
\hline $\mathrm{D}=30 \mathrm{ppt}$ & $0.08 \pm 0.03$ & $0.54 \pm 0.06$ & $0.48 \pm 0.09^{b}$ & $0.93 \pm 0.02$ & $1.20 \pm 0.02$ & $0.27 \pm 0.02^{b}$ \\
\hline
\end{tabular}

Different letter at the same column are shown significantly different at a level $5 \%(p<0,05)$.

Table 1: Weight increment $(\mathrm{g})$ and carapace width $(\mathrm{cm})$ of crablet, $S$. olivacea after reared during one month at the different salinity regimes. 


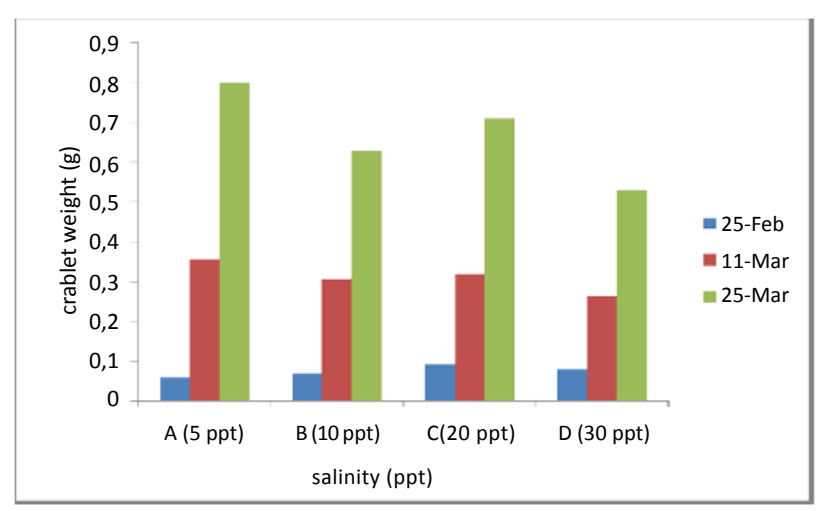

Figure 2: Crablet S. Olivacea weight increment at the different salinity regimes.

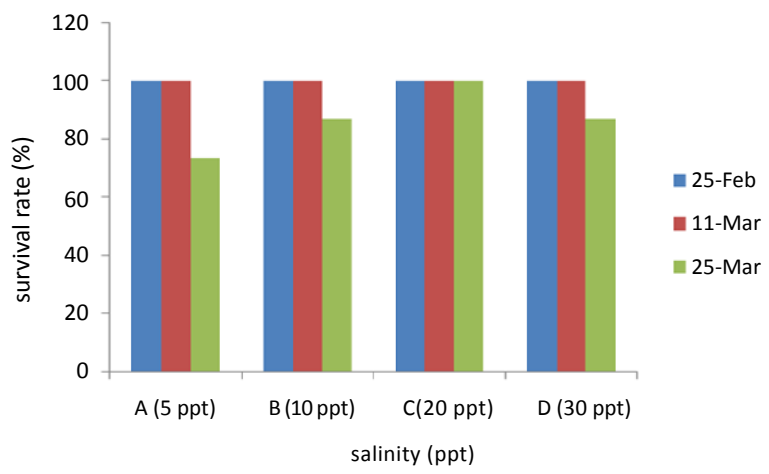

Figure 3: Survival rate of crablet S. Olivacea reared at the different salinity regimes.

\begin{tabular}{|l|l|l|l|l|}
\hline Treatment & $\begin{array}{l}\text { Water quality } \\
\left({ }^{\circ} \mathbf{C}\right)\end{array}$ & $\mathbf{p H}$ & $\begin{array}{l}\text { Dissolved } \\
\text { Oxsigen (ppm) }\end{array}$ & $\begin{array}{l}\text { Alkalinity } \\
\text { (ppm) }\end{array}$ \\
\hline A (5 ppt) & $25-25.8$ & $8.1-8.8$ & $4.6-5.7$ & $104.6-160$ \\
\hline B (10 ppt) & $25-26.0$ & $8.1-8.9$ & $4.9-5.6$ & $104.6-160$ \\
\hline C (20 ppt) & $25.1-26.0$ & $8.0-8.9$ & $4.5-5.3$ & $139.5-204.9$ \\
\hline D (30 ppt) & $25.1-25.8$ & $8.0-8.7$ & $4.4-5.1$ & $91.6-213.6$ \\
\hline
\end{tabular}

Table 2: Some water quality parameters in crablet rearing at the different salinity regimes.

amount in the crablet were sufficient to support complete molting in all crablet, those was resulted crablet survival rate $100 \%$ in one month rearing.

\section{Water quality}

Some water quality parameter monitored were presented in Table 2. Water temperature as the environmental factor controlling to the metabolism acceleration process, oxygen consumption, growth and survival of organisms cultured [16]. Water temperature in the morning at 8.00-9.00 showing not significantly different among the four treatments tested, namely $25-25.8^{\circ} \mathrm{C}(\mathrm{A}), 25-26^{\circ} \mathrm{C}(\mathrm{B}), 25.1-26^{\circ} \mathrm{C}$ (C) and $25.1-25,8^{\circ} \mathrm{C}(\mathrm{D})$. Water $\mathrm{pH}$ relatively stable at the range 8.1 8.8 (A), 8.1-8.9 (B), 8.0-8.9 (C) and 8.0-8.7 (D). Dissolved oxygen at 4.6-5.7 ppm (A), 4.9-5.6 ppm (B), 4.5-5.3 ppm (C) and 4.4-5.1 ppm (D) were seemed high it caused by the addition of aeration supplied to the each aquarium. The relationship between oxygen consumption and salinity regimes for crab rearing was studied by Karim and Syahrul
[17] and they found that the lowest oxygen consumption was 0.23 $\mathrm{mg} / \mathrm{g}$ body weight/hour at the rearing salinity $25 \mathrm{ppt}$ and the high oxygen consumption at $0.37 \mathrm{mg} / \mathrm{g}$ body weight/hour at salinity $5 \mathrm{ppt}$. Dissolved oxygen in all treatments were $>4 \mathrm{mg} / \mathrm{L}$, and that condition was not a limiting factor to the crablet growth.

Alkalinity range was 105-160 ppm (A), 105-160 ppm (B), 139-205 ppm (C) and 92-214 ppm (D). The suitable alkalinity for crablet rearing can be interpreted on the relationship between alkalinity and the crablet survival rate in each treatment. It was performed in $\mathrm{C}$ treatment at the range $139-205 \mathrm{ppm}$, where crablet survival rate attains $100 \%$ and not any crablet failure molt during one month rearing.

\section{Conclusion}

The salinity 5 ppt was performed highest growth weight, while salinity $20 \mathrm{ppt}$ was performed highest survival rate. The salinity ranged 5-20 ppt could be better for crablet $S$. olivacea rearing to increase growth weight and survival rate.

\section{References}

1. Keenan CP, Davie PJF, Mann DL (1998) A revision of the Genus Scylla de Haan, 1833 (Crustacea: Decapoda: Brachyura: Portunidae). Raffles Bull Zool 46: 217-245.

2. Gunarto, Daud, Usman R (1999) Tend to decrease of mangrove crab, Scylla sp population in Cenrana mouth river, Bone Regency, South Sulawesi. Coastal Fisheries Research Journal 5: 30-37.

3. Anonymous (2009) Mud crab culture in Segara Anakan. Review of mud crab culture research in Indonesia.

4. Nurjanah (2008) Analisys on the prospect of brackishwater aquaculture Brebes regency, Cermin.

5. Gunarto, Zakaria M (2013) Rearing of mangrove crab Scylla olivacea megalops using different kind of tank. Paper presented in the Indonesian Aquaculture Conferences.

6. Des Roza (1999) Control of Vibrio harveyi in mangrove crab, Scylla serrata Forskal larvae through desinfection on the female spawned during incubation. Indonesian Aquaculture Research Journal 5: 28-33.

7. Suprayudi MA, Takeuchi T, Hamazaki K (2004) Effect of artemia enriched with eicosapentaenoid and docosahexaenoic acid on survival and occurrence of moulting failure in megalop larvae of the mud crab Scylla serrata. Fisheries science 70: 650-658.

8. Gunarto (2012) The effect of seaweed, Gracilaria sp as a shelter in mangrove crab, Scylla olivacea crablet rearing. Proceeding of the National Seminar of Indonesian Fisheries. Result of Fisheries and marine research: 76-82.

9. Mia MY, Shah MMR (2010) Effect of salinity on the survival and growth of mud crabling, Scylla serrata. Univ J zool Rajshahi Univ 29: 29-32.

10. Djunaidah IS, Toelihere MR, Effendie MI, Sukimin S, Riani E (2004) The growth and survival rate on the mangrove crab, Scylla paramamosain juvenile reared in the different substrate. Marine Sciences Journal 9: 20-25.

11. Lewis LV, Lebata JH, Walton ME, Primavera J, Quinitio E, et al., (2008) Approaches to stock enhancement in mangroveassociated crab fisheries. Fisheries Science 16: 72-80.

12. Suwirya K, Zafril IA, Rochimat T (1986) Rearing of post larvae, Penaeus monodon at the different salinity regimes in laboratory. Coastal Aquaculture Research Journal 1: 34-39.

13. Greenaway $P$ (1985) Calcium balance and molting in the crustacea. Biological Reviews 60: 425-454.

14. Salaenoi J (2004) Changes of enzymes and epidermal components during molting stages of mud crab (Scylla serrata Forskal 1775). Department of Bioscience, Kasetsart University, Bangkok, Thailand.

15. Salaenoi J, Bootpugdeethum J, Mingmuang M, Thongpan A (2006) Variation of Calcium, $\mathrm{N}$-acetylglucosamin, glucosamin and glucosa content during molting cycle of mud crab (Scylla serrata Forskal 1775). Kasetsart J: Nat Sci 40: 668679. 
Citation: Gunarto and A. Parenrengi (2014) Crablet of Mangrove Crab, Scylla olivacea Rearing at the Different Salinity Regimes. J Aquac Res Development 5: 255 doi:10.4172/2155-9546.1000255

Page 4 of 4

16. Lu-Qing P, Bo F, Ling-Xu J, Jing $L$ (2007) The effect of temperature on selected immune parameters of white shrimp, Litopenaeus vannamei. Journal of the World Aquaculture Society 38: 326-332
17. Karim MY, Syahrul (2006) Oxygen consumption in mangrove crab, Scylla serrata Forskal, at the different salinity regimes. Research Report, Faculty of Marine and Fisheries, Hasanuddin University, Indonesia. 